7. Reprod. Fert. (1975) 45, 165-167

\title{
EFFECTS OF LONG-TERM CADMIUM EXPOSURE ON THE SEMINAL VESICLES OF MICE
}

\author{
G. F. NORDBERG \\ Department of Environmental Hygiene, Karolinska Institute, and \\ Department of Environmental Hygiene, National Environmental Protection Board, \\ S-104 01 Stockholm, Sweden
}

(Received 6th February 1975)

\begin{abstract}
Summary. Male CBA-mice were exposed to cadmium by subcutaneous injection of $2 \cdot 2 \mu \mathrm{mol} \mathrm{CdCl} / 2 / \mathrm{kg}$ body weight for 5 days $/$ week for 6 months. A decrease in normal (testosterone-dependent) proteinuria was shown, and morphological examination of the seminal vesicles revealed a smaller weight and size as well as histological indication of lower secretory activity of the epithelium compared to controls. The findings are consistent with a theory implying a decreased testosterone activity in cadmium-treated animals.
\end{abstract}

Acute doses of cadmium are known to have a destructive action on testicular tissue (Parizek, 1960; Gunn \& Gould, 1970; Friberg et al., 1974). Long-term exposure through smaller daily doses of cadmium does not have this effect in spite of higher concentrations of cadmium being present in testicular tissue (Nordberg, 1971). Such exposure to cadmium gives rise to renal tubular dysfunction in various mammals (Friberg et al., 1974). Nordberg \& Piscator (1972) noted a significant decrease in the protein excretion of male mice before the onset of renal tubular dysfunction. Since the normal proteinuria in mice is known to be testosterone-dependent (Thung, 1956; Finlayson et al., 1965), the decreased production of testosterone may therefore be an early effect of longterm cadmium exposure. This possibility was investigated by studying the morphology of the seminal vesicles which is influenced by testosterone (Moore, 1935).

Male CBA-mice weighing about $30 \mathrm{~g}$ were used. Their source and housing were as described by Nordberg \& Piscator (1972). Eight mice were given daily subcutaneous injections of $2 \cdot 2 \mu \mathrm{mol} \mathrm{CdCl}_{2} / \mathrm{kg}$ body weight on 5 days each week for 6 months. Eight control mice were similarly injected with iso-osmotic $(0.9 \%)$ sodium chloride. Urine was collected from individual animals in metabolism cages before the injections were started and at 6 weeks and 25 weeks after the experiment had begun. Protein analysis was performed according to the methods described by Nordberg \& Piscator (1972).

The animals were killed by cervical dislocation, and the seminal vesicles plus the prostate were dissected out. The organs were fixed for $24 \mathrm{hr}$ in Bouin's fluid, and then the individual seminal vesicles were dissected free from the prostate and weighed. Tissues were dehydrated in alcohol, cleared in methyl 
benzoate, embedded in fibrowax, serially sectioned at $4 \mu \mathrm{m}$, mounted 1 in 20 , and stained in haematoxylin and eosin. Care was taken while embedding the seminal vesicles to obtain sections as transverse as possible. The largest and smallest diameters of each of the series sections were measured. The largest of the respective diameters was used for evaluation of the size of the organ. The testes were also removed at autopsy, and were weighed, prepared for histological examination and classified by the criteria of Nordberg (1971). Mean values were compared by Student's $t$ test.

There were no outward signs of toxicity in any of the treated animals, but after exposure for 6 months the mean body weight of the Gd-treated animals was $27 \cdot 1 \pm 1.66 \mathrm{~g}$ (S.D.) compared with that of $31 \cdot 1 \pm 2.64 \mathrm{~g}(P<0.01)$ for controls.

The urinary excretion of protein ( $\mathrm{mg}$ protein/mg creatinine) was lower in the treated mice compared with controls after 6 weeks $(18 \cdot 1 \pm 2.03$ versus $22 \cdot 8 \pm$ 2.03 ) and more prominently so after 6 months (5.8 \pm 3.99 (six values only) versus $14 \cdot 8 \pm 3 \cdot 25)$. These observations are in accord with those of Nordberg \& Piscator (1972), the differences in the control values being due to seasonal variations in testosterone production.

Testicular weight and histology did not differ in the two groups.

A statistically significant lower mean weight and diameter of the crosssectioned vesicles (Table 1) was observed in the rats exposed to Cd compared to controls. There was a difference in the secretory activity of the cells of the vesicular epithelium in the two groups (Pl. 1, Figs 1 and 2), but a range of appearance was found in both groups and a scoring system and statistical evaluation was not possible.

Table 1. The mean ( \pm S.D.) weight and size of seminal vesicles in mice exposed to cadmium

\begin{tabular}{lrrr}
\hline & Cd-exposed & Controls & $\begin{array}{c}\text { Student's } \\
\mathrm{t} \text {-test }\end{array}$ \\
\hline Weight $(\mathrm{mg})$ & & $14 \cdot 58 \pm 4 \cdot 07$ & $P<0.01$ \\
Largest diameter $(\mathrm{mm})$ & $3 \cdot 15 \pm 2 \cdot 84$ & $3 \cdot 80 \pm 0 \cdot 22$ & $P<0.01$ \\
Smallest diameter $(\mathrm{mm})$ & $2 \cdot 25 \pm 0 \cdot 48$ & $2 \cdot 16 \pm 0 \cdot 20$ & $P<0.01$ \\
\hline
\end{tabular}

The observed decreases in seminal vesicle weight, diameter and activity of epithelium in Cd-exposed animals show that there is an effect of cadmium on this organ, which is similar to that expected when the organ is subjected to decreased testosterone levels. The changes were not as prominent as those seen after castration or a single large dose of cadmium (Parizek, 1960). It cannot be excluded, however, that the effect on the seminal vesicles was due to a direct effect of cadmium on this organ, but this is unlikely since there was also a clear effect on the testosterone-dependent proteinuria in the mice. The fact that cadmium accumulates in the interstitial tissue of the testes (Nordberg, 1972) is also in accord with the theory that cadmium influences the production of testosterone. Definite confirmation, however, must await chemical determinations of testosterone and its metabolites in tissues and urine from mice.

Even though an effect on testosterone production is likely to be present in these mice treated for long periods with small doses of cadmium they were not 
PLATE 1

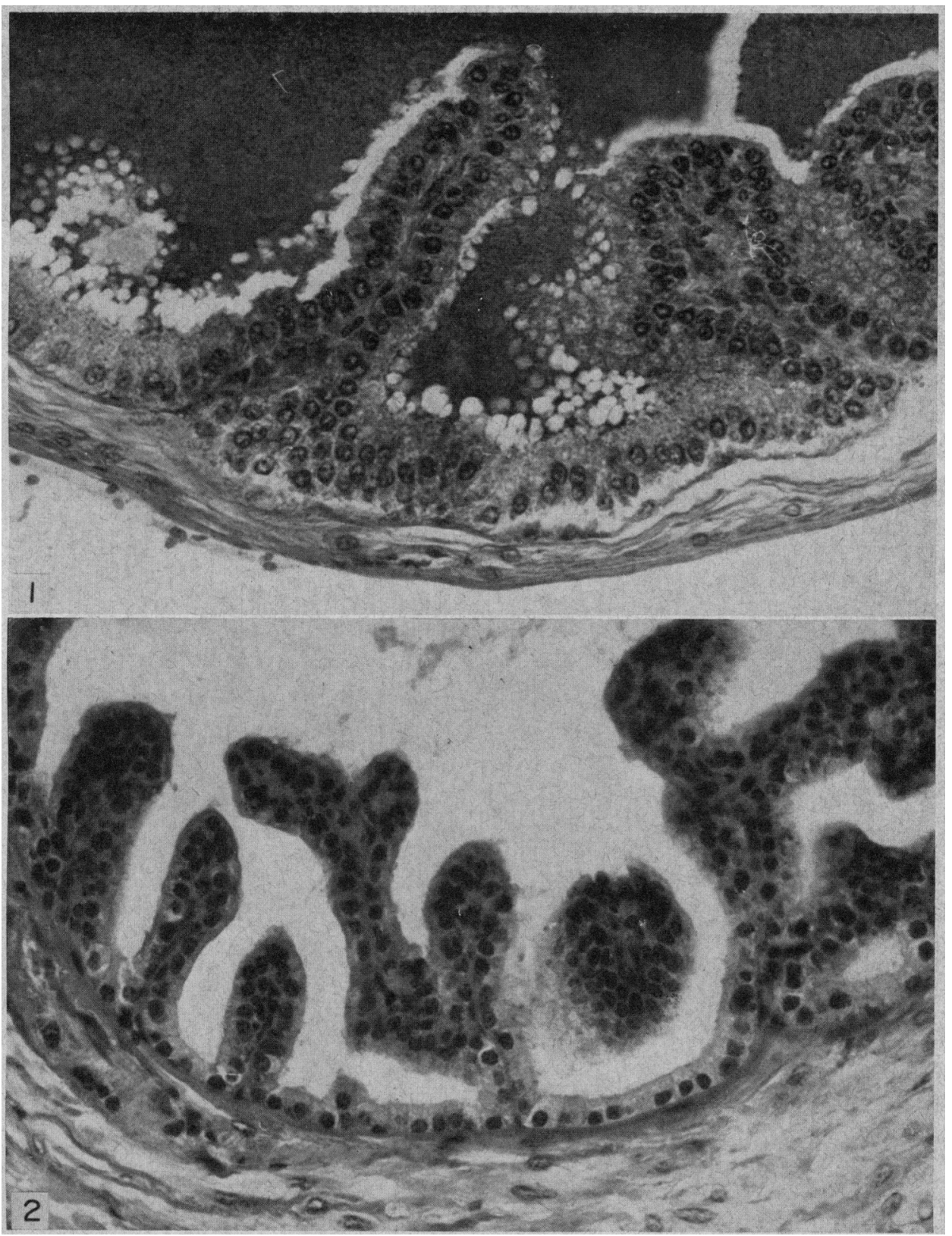

Sections of the seminal vesicles of mice. $\times 300$.

Fig. 1. A control animal, showing the high columnar epithelium indicative of secretory activity

Fir. 2. In animal exposed to cadmium for 6 months, showing a low cuboidal cpithelium. 
completely infertile (Nordberg, 1971). Favino et al. (1968) studied fertility and androgen excretion in ten men exposed to cadmium oxide dust, and found one case of impotence with low urine levels of 17-ketosteroids, androsterone and etiocholanolone, but there was no statistically significant difference in relation to controls. Further studies on men exposed to cadmium would be of interest in view of the results reported in the present paper.

The technical assistance of Ms Gunnel Grabergs is appreciated. A grant from the Swedish Medical Research Council (Project No. 03X775) is gratefully acknowledged. Funds provided by U.S. Environmental Protection Agency made possible the publication of this paper.

\section{REFERENGES}

Favino, A., Candura, F., Chiappino, G. \& Gavalieri, A. (1968) Study on the androgen function of men exposed to cadmium. Medna Lav. 59, 105-107.

Finlayson, J.S., Asofsky, R., Potter, M. \& Runner, C.C. (1965) Major urinary protein complex of normal mice-origin. Science, N.Y. 149, 981-982.

Friberg, L., Piscator, M., Nordberg, G.F. \& KJellstrom, T. (1974) Cadmium in the Environment, 2nd C.R.C. Press Division, Ghemical Rubber Co., Gleveland.

Gunv, S.A. \& Gould, T.C. (1970) Cadmium and other mineral elements. In The Testis, Vol. III, pp. 377-401. Eds A. D. Johnson, W. R. Gomes \& N. L. VanDemark. Academic Press, New York and London.

Moore, G.J. (1935) Glandular physiology and therapy. The testis hormone. F. Am. med. Ass. 104, 14051411.

NorDBerg, G.F. (1971) Effects of acute and chronic cadmium exposure on the testicles of mice, with special reference to protective effects of metallothionein. Environ. Physiol. Biochem. 1, 171-187.

NordBerg, G.F. (1972) Cadmium metabolism and toxicity, experimental studies on mice with special reference to the use of biological materials as indices of retention and the possible role of metallothionein in transport and detoxification of cadmium. Environ. Physiol. Biochem. 2, 7-36.

NoRdBerg, G.F. \& Piscator, M. (1972) Influence of long-term cadmium exposure on urinary excretion of protein and cadmium in mice. Environ. Physiol. Biochem. 2, 37-49.

ParizeK, J. (1960) Sterilization of the male by cadmium salts. F. Reprod. Fert. 1, 294-309.

Thung, P.J. (1956) Proteinuria in mice and its relevance to comparative gerontology. Expelle Alternsforsch. 4, 195-198. 